\title{
Assessment of Saturated Soil Paste Salinity from 1:2.5 and 1:5 Soil-Water Extracts for Coarse Textured Soils
}

\author{
Emad F. Aboukila *, and Emad F. Abdelaty 1
}

\begin{abstract}
It is important to determine soil salinity with an accurate and simple method. Electrical conductivity (EC) of soil-water extracts is commonly used to assess soil salinity because it is an easier method than the standard saturated paste extract $\left(\mathrm{EC}_{\mathrm{e}}\right)$. However, it is essential to convert EC of soil-water extracts to $\mathrm{EC}_{\mathrm{e}}$ because plant response and salinity remediation are based mainly on $\mathrm{EC}_{\mathrm{e}}$ values. Our objectives were to develop and validate models to predict $\mathrm{EC}_{\mathrm{e}}$ from $\mathrm{EC}$ of 1:2.5 and 1:5 soil-water extracts $\left(\mathrm{EC}_{1: 2.5}, \mathrm{EC}_{1: 5}\right)$. One hundred thirty-six coarse textured soil samples were collected from El Beheira Governorate, Egypt, of which 115 were used to develop models and 21 were used to validate these models. Electrical conductivity was determined using 1:2.5 and 1:5 soil-water extracts and saturated paste extracts $\left(\mathrm{EC}_{\mathrm{e}}\right)$. Linear regression models were established for the two methods. The results showed that $\mathrm{EC}_{\mathrm{e}}$ was highly significant correlated $\left(\mathrm{R}^{2}=0.96\right.$ to $\left.0.97, P<0.001\right)$ with $\mathrm{EC}_{1: 2.5}$ and $\mathrm{EC}_{1: 5}$ for $\mathrm{EC}_{\mathrm{e}}$ values ranging between 0.3 and $18.3 \mathrm{dS} \mathrm{m}^{-1}$. An independent validation set of 21 soil samples showed that the $R^{2}$ and slopes of the regressions between predicted $\mathrm{EC}_{\mathrm{e}}$ from both $\mathrm{EC}_{1: 2.5}$ and $\mathrm{EC}_{1: 5}$ values and direct $\mathrm{EC}_{\mathrm{e}}$ values were very close to 1.0. Additionally, these new models reduced ECe prediction errors by 2.4 to 7 times when compare with 8 predictive models reported in the literature. Confirming that the regressions developed can reliably assess soil salinity instead of the more timeconsuming and expensive saturated paste extraction.
\end{abstract}

Key Words: Soil salinity, Electrical conductivity, Saturated soil paste, Soil-water extract.

\section{INTRODUCTION}

It is crucial to determine the suitability of soils in terms of soil salinity in order to produce crop (Kruse et al., 1990) and plan to make disrupted soils fit for cultivation (Day et al., 2015). Electrical conductivity (EC) of a soil extract is commonly utilized as a parameter for identifying soil salinity and estimating the concentration of ions within the soil (Aboukila and Norton, 2017). Nowadays, saturated paste (SP) extract and soil-water extracts are the extraction methods that are applied for soil salinity. Not only the EC of SP extract $\left(\mathrm{EC}_{\mathrm{e}}\right)$ is recommended as a standard laboratory method for estimating the EC of soil but also it is taken into consideration to be the best indicator of plant response to salinity compared with more dilute soilwater extractions (Herrero and Pérez-Coveta, 2005). Soil management elucidations are based on values obtained from $\mathrm{EC}_{\mathrm{e}}$.

Saturated paste extracts are demanding, time consuming and more skills are needed for determining the correct saturation point (Al-Busaidi et al., 2006); therefore, in view of these reasons, it is an uneasy and costly method to determine soil salinity for high sampling frequency (Aboukila and Norton, 2017). Considering all the situations, a much easier, quick, and efficient method is demanded in order to estimate soil salinity with less equipment.

In contrast to SP extracts, soil-water extracts can be composed and derived in a much easy way. To determine the EC values of soils, soil-water extracts of $1: 1,1: 2,1: 2.5,1: 5$, and $1: 10$ have been commonly utilized in soil laboratories (Hogg and Henry, 1984; Zhang et al., 2005; Sonmez et al., 2008; Chi and Wang, 2010; Khorsandi and Yazdi, 2011; He et al., 2013; Klaustermeier et al., 2016; Monteleone et al., 2016; Aboukila and Norton, 2017). The 1:5 ratio is preferably used as a method for calculating soil salinity in Australia, China, and Central Asia (Shirokova et al., 2000; Wang et al., 2011) as well as 1:1 ratio in the United States and Canada (Hogg and Henry, 1984; He et al., 2013). Albeit, in contrast to the SP extract method, soil-water extracts are considered to be less connected to natural soil conditions (Rhoades, 1996). Ion concentrations and electrical conductivities of SP extracts are typically higher than those of the different soil-water extracts in consequence of the enhanced dilution effect (Sonmez et al., 2008). The biggest drawback of utilizing soil-water extract is the influence of water on dissolution of less soluble salts, such as gypsum and calcite (Rhoades et al., 1999). Higher variation of ionic ratios is caused because of increasing the dilution of the soil-water extract compared to the natural soil solution as varying amounts of less soluble

\footnotetext{
${ }^{1}$ Assistant Professor, Department of Natural Resources and

Agricultural Engineering, College of Agriculture, Damanhour

University, Damanhour, Egypt

*Corresponding Author: Emad F. Aboukila. College of Agriculture,

Damanhour University, Al Abadia Campus, Damanhour, Egypt.

Phone: +2 01092692607, Fax: +2 0453282303,

Email:emad@damanhour.edu.eg

Received October 10,2017, Accepted November07, 2017
} 
salts are dissolved (Monteleone et al., 2016). Corwin et al. (2012) reported that the causes for these diversions are ion hydrolysis, mineral dissolution, and alterations in exchangeable cation ratios. Gypsum leads to enhancing deviations in soils, since the concentrations of ions abate with enhancing dilution while the concentrations of calcium and sulfate stay nearly constant with dilution (Corwin et al., 2012).

The advantages of soil-water extracts are that they require less labor, quicker and can be useful when the objectives are to evaluate the relative changes rather than the absolute solute content (McKenzie et al., 1983; Rhoades, 1996). Since soil-water extract methods can be conducted with relative ease, there have been theoretical relationships developed to convert soil-water extraction results to a SP extraction equivalents (USDA, 1954; Hogg and Henry, 1984; Zhang et al., 2005; Sonmez et al., 2008; Chi and Wang, 2010; Khorsandi and Yazdi, 2011; He et al., 2013; Klaustermeier et al., 2016; Monteleone et al., 2016; Aboukila and Norton, 2017). Despite the reports of highly correlated relationships between the two methods for particular soils, converted values are often imprecise and inaccurate (Wagenet and Jurinak, 1978; Franzen, 2003) especially, if conversion equations are applied to larger regions or different soils (He et al., 2013). Therefore, further studies based on adjusted soil-water extract analysis of soil salinity is necessary to improve soil remediation strategies.

Good relationships have been reported between $\mathrm{EC}_{\mathrm{e}}$ and 1:1 extracts and suspensions (Wagenet and Jurinak, 1978; Fowler and Hamm, 1980; Hogg and Henry, 1984; Pitman et al., 2002; Zhang et al., 2005; Klaustermeier et al., 2016; Monteleone et al., 2016), 1:2 extracts and suspensions (McKenzie et al, 1983; Hogg and Henry, 1984; Khorsandi and Yazdi 2007; Monteleone et al., 2016), 1:2.5 extracts (Ozcan et al., 2006; Sonmez et al., 2008; Aboukila and Norton, 2017) and 1:5 extracts and suspension (Alavi Panah and De Dapper, 2001; Khorsandi and Yazdi, 2011; He et al., 2013; Klaustermeier et al., 2016; Monteleone et al., 2016; Aboukila and Norton, 2017).

There is a considerable difference when comparing the $\mathrm{EC}_{\mathrm{e}}$ to $\mathrm{EC}$ relationships of different soil-water extract from previous studies, thus uncertainties exist and when applying models from one study to soils from another region. There is limited knowledge and understanding of the transferability of the conversion models because of the uncertainty. Thus, a better understanding of the transferability of these models would provide managers more information about the accuracy of the $\mathrm{EC}_{\mathrm{e}}$ values derived from non-local EC conversion models (Khorsandi and Yazdi, 2011; Aboukila and Norton, 2017). Further examination and comparison of these two methods are needed, especially for different soil texture groups (Sonmez et al., 2008; Monteleone et al., 2016).

The variations in conversion factors make it necessary to examine and compare the different soilwater extraction methods with SP. Furthermore, in soil laboratories, $\mathrm{pH}$ is measured in 1:2.5 soil-water extracts. If suitable conversion coefficients were determined, EC may also be measured in the same extract, therefore saving analysis time (Sonmez et al., 2008).

The relationships between $\mathrm{EC}_{\mathrm{e}}$ and $\mathrm{EC}$ of different soil-water extracts are affected by soil texture, salts present in the soil and presence of gypsum (USDA, 1954; Richard and Gouny, 1965; Le Brusq and Loyer, 1982; Alavi Panah and De Dapper, 2001). Another factor that has likely influenced differences among models is equilibration times and equilibration methods (He et al., 2013). Khorsandi and Yazdi (2007, 2011) reported considerable improvement in the prediction of $\mathrm{EC}_{\mathrm{e}}$ from $\mathrm{EC}$ of 1:2 and 1:5 extracts and 1:5 suspension by categorizing the soils into groups with or without gypsum.

Within many regions around the world, Egypt not being an exception, hundreds of soil samples are routinely analyzed by either government or commercial soil-testing laboratories. Because of the lack of facilities within these labs, $\mathrm{EC}_{1: 2.5}$ and $\mathrm{EC}_{1: 5}$ are commonly used to determine the EC value of the samples. To classify soil salinity for management decisions the soil-water extract $\mathrm{EC}$ values are then used instead of $\mathrm{EC}_{\mathrm{e}}$ values. Until now there has not been any $\mathrm{EC}_{\mathrm{e}}$ to $\mathrm{EC}$ of soilwater extract studies conducted on the coarse textured soils of the El Beheira Governorate, which is the biggest and most agriculturally important region in Egypt. The objective of this study was to determine the relationships between the $\mathrm{EC}_{\mathrm{e}}$ and the $\mathrm{EC}$ of 1:2.5, 1:5 soil-water extraction ratios for coarse textured soil collected from El Beheira Governorate, Egypt, and to compare those values with $\mathrm{EC}_{\mathrm{e}}$ derived from models developed for other, or more broad, regions.

\section{MATERIALS AND METHODS}

\section{Soil Samples}

Soil samples $(n=136)$ were collected from south of El Beheira Governorate in the northern part of Egypt (approximate latitude between $30^{\circ} 05^{\prime} 55^{\prime \prime}$ and $30^{\circ} 46^{\prime}$ $44^{\prime \prime} \mathrm{N}$, and between $29^{\circ} 57^{\prime} 51^{\prime \prime}$ and $30^{\circ} 51^{\prime} 27^{\prime \prime} \mathrm{E}$ ). The general topography is level. The mean annual temperature is $20.6^{\circ} \mathrm{C}$, average high temperature is $27.5^{\circ} \mathrm{C}$ and mean low temperature is $13.7^{\circ} \mathrm{C}$. Annual precipitation is $53 \mathrm{~mm}$, mainly falling in the months of November through February (Climate-Data.org, 2016). 
Table 1. Correlation equations established by different studies to convert soil-water extracts at different ratios $\left(E_{1: x}\right)$ to saturated paste $\left(E C_{e}\right)$ equivalents

\begin{tabular}{|c|c|c|c|c|c|}
\hline \multirow[t]{2}{*}{ Study } & \multicolumn{4}{|c|}{ Regression equation } & \multirow[t]{2}{*}{ EC $_{\text {e }}$ Range $^{a}$} \\
\hline & With intercept & $\mathbf{R}^{2}$ & Without intercept & $\mathbf{R}^{2}$ & \\
\hline USDA (1954) & & & $\mathrm{EC}_{\mathrm{e}}=3.00 \mathrm{EC}_{1: 1}{ }^{\mathrm{b}}$ & 0.96 & $\mathrm{~N} / \mathrm{A}^{\mathrm{g}}$ \\
\hline \multirow[t]{2}{*}{ Hogg and Henry (1984) } & $\mathrm{EC}_{\mathrm{e}}=2.06 \mathrm{EC}_{1: 1}+0.05^{\mathrm{c}}$ & 0.97 & & & $0.10-22.4$ \\
\hline & $\mathrm{EC}_{\mathrm{e}}=2.79 \mathrm{EC}_{1: 2}+0.17^{\mathrm{c}}$ & 0.91 & & & $0.10-22.4$ \\
\hline Zhang et al. (2005) & $\mathrm{EC}_{\mathrm{e}}=1.79 \mathrm{EC}_{1: 1}+1.46^{\mathrm{b}}$ & 0.85 & $\mathrm{EC}_{\mathrm{e}}=1.85 \mathrm{EC}_{1: 1} \mathrm{~b}$ & 0.85 & $0.16-108$ \\
\hline \multirow[t]{3}{*}{ Ozcan et al. (2006) } & $\mathrm{EC}_{\mathrm{e}}=1.93 \mathrm{EC}_{1: 1}-0.57$ & 0.96 & & & N/A \\
\hline & $\mathrm{EC}_{\mathrm{e}}=3.30 \mathrm{EC}_{1: 2.5}-0.20$ & 0.95 & & & N/A \\
\hline & $\mathrm{EC}_{\mathrm{e}}=5.97 \mathrm{EC}_{1: 5}-1.17$ & 0.94 & & & N/A \\
\hline \multirow[t]{3}{*}{ Sonmez et al. (2008) } & $\mathrm{EC}_{\mathrm{e}}=2.72 \mathrm{EC}_{1: 1}-1.27^{\mathrm{c}}$ & 0.99 & $\mathrm{EC}_{\mathrm{e}}=2.42 \mathrm{EC}_{1: 1} \mathrm{c}$ & 0.98 & $0.22-17.7$ \\
\hline & $\mathrm{EC}_{\mathrm{e}}=4.34 \mathrm{EC}_{1: 2.5}+0.17^{\mathrm{c}}$ & 0.99 & $\mathrm{EC}_{\mathrm{e}}=4.41 \mathrm{EC}_{1: 2.5}{ }^{\mathrm{c}}$ & 0.99 & $0.22-17.7$ \\
\hline & $\mathrm{EC}_{\mathrm{e}}=8.22 \mathrm{EC}_{1: 5}-0.33^{\mathrm{c}}$ & 0.98 & $\mathrm{EC}_{\mathrm{e}}=7.98 \mathrm{EC}_{1: 5}{ }^{\mathrm{c}}$ & 0.98 & $0.22-17.7$ \\
\hline Chi and Wang (2010) & $\mathrm{EC}_{\mathrm{e}}=11.68 \mathrm{EC}_{1: 5}-5.77^{\mathrm{b}}$ & 0.94 & & & $1.00-227$ \\
\hline Khorsandi and Yazdi & $\mathrm{EC}_{\mathrm{e}}=5.43 \mathrm{EC}_{1: 5}+0.43^{\mathrm{d}}$ & 0.96 & $\mathrm{EC}_{\mathrm{e}}=5.48 \mathrm{EC}_{1: 5}^{\mathrm{d}}$ & 0.96 & $0.63-91.7$ \\
\hline (2011) & $\mathrm{EC}_{\mathrm{e}}=5.75 \mathrm{EC}_{1: 5}-4.45^{\mathrm{e}}$ & 0.97 & $\mathrm{EC}_{\mathrm{e}}=5.37 \mathrm{EC}_{1: 5} \mathrm{e}^{\mathrm{e}}$ & 0.96 & $0.54-126$ \\
\hline Monteleone et al. (2016) & & & $\mathrm{EC}_{\mathrm{e}}=9.63 \mathrm{EC}_{1: 2.5}{ }^{\mathrm{b}}$ & 0.99 & $0.15-62.9$ \\
\hline Klaustermeier et al. (2016) & $\mathrm{EC}_{\mathrm{e}}=10^{\left[1.256\left(\log \mathrm{EC}_{1: 5}\right)+0.766\right] \mathrm{b}}$ & 0.97 & & & $0.41-126$ \\
\hline \multirow[t]{2}{*}{ Aboukila and Norton (2017) } & $\mathrm{EC}_{\mathrm{e}}=3.05 \mathrm{EC}_{1: 2.5}+0.41^{\mathrm{f}}$ & 0.93 & $\mathrm{EC}_{\mathrm{e}}=3.34 \mathrm{EC}_{1: 2.5}{ }^{\mathrm{f}}$ & 0.92 & $0.62-10.3$ \\
\hline & $\mathrm{EC}_{\mathrm{e}}=5.04 \mathrm{EC}_{1: 5}+0.37^{\mathrm{f}}$ & 0.93 & $\mathrm{EC}_{\mathrm{e}}=5.49 \mathrm{EC}_{1: 5}{ }^{\mathrm{f}}$ & 0.92 & $0.62-10.3$ \\
\hline \multirow[t]{2}{*}{ This study } & $\mathrm{EC}_{\mathrm{e}}=3.73 \mathrm{EC}_{1: 2.5}+0.79^{\mathrm{c}}$ & 0.96 & $\mathrm{EC}_{\mathrm{e}}=4.13 \mathrm{EC}_{1: 2.5^{\mathrm{c}}}$ & 0.94 & $0.29-18.3$ \\
\hline & $\mathrm{EC}_{\mathrm{e}}=7.46 \mathrm{EC}_{1: 5}+0.43^{\mathrm{c}}$ & 0.97 & $\mathrm{EC}_{\mathrm{e}}=7.89 \mathrm{EC}_{1: 5}{ }^{\mathrm{c}}$ & 0.96 & $0.29-18.3$ \\
\hline
\end{tabular}

${ }^{a}$ Units of EC are in $\mathrm{dS} \mathrm{m} \mathrm{m}^{-1}$

${ }^{\mathrm{b}}$ Combined soil textures.

c Coarse textured soils.

${ }^{\mathrm{d}}$ Coarse textured soils without gypsum.

e Coarse textured soils with gypsum.

${ }^{\mathrm{f}}$ Fine textured soils.

g Data not available.

The soil samples were collected from 136 different agricultural sites, at the depths of $0-30 \mathrm{~cm}$. Of the 136 samples, 115 were used to develop the relationships, and 21 were used for validation the relationships. The soils are classified as Typic Torripsamments (Soil Survey Staff, 2014). The soil texture ranged from sand to sandy loam. Each sample was air-dried, ground, sieved through a 2-mm sieve, and stored in plastic bags for analysis.

Soil $\mathrm{pH}$ was measured in a 1:2.5 soil-water suspension. Soil texture was determined by the hydrometer method (Gee and Bauder, 1986). Calcium carbonate equivalent (CCE) was estimated by pressurecalcimeter methods (Nelson, 1982). Organic matter content (OM) was determined by the dichromate oxidation method (Nelson \& Sommers, 1982) (Table 2).

\section{Saturated Paste (SP) Extraction}

The EC of SP of each soil sample was determined using the methods outlined by USDA (1954). Saturated paste extracts were prepared by adding distilled water to approximately $500 \mathrm{~g}$ soil and stirring until complete saturation occurred. The SP was allowed to equilibrate for $18 \mathrm{~h}$. Vacuum extracts were obtained and filtered using Whatman No. 42 filter paper into 50-ml polyethylene bottles, and the $\mathrm{EC}_{\mathrm{e}}$ were measured at $25^{\circ} \mathrm{C}$ using a Jenway 4510 Conductivity Meter.

\section{Soil-Water Solution Extractions}

Prior to extraction, $25 \mathrm{~g}$ of each soil sample was oven dried overnight at $105^{\circ} \mathrm{C}$ to determine gravimetric water content. An appropriate amount of distilled water was added to $50 \mathrm{~g}$ of air-dried soil to create a 1:2.5 soilwater suspension. A 1:5 soil-water suspension was prepared by adding the appropriate amount of distilled water to $25 \mathrm{~g}$ of air-dried soil. The 1:2.5 and 1:5 the soil-water suspensions were allowed to equilibrate for $23 \mathrm{~h}$ prior to agitation with a mechanical shaker (132 rev $\mathrm{min}^{-1}$ ) for $1 \mathrm{~h}$ (Soil Survey Staff, 2011). After agitation, the soil solutions were filtered through a Whatman No. 42 filter paper into $50-\mathrm{mL}$ polyethylene bottles, and the 
EC readings were measured at $25^{\circ} \mathrm{C}$ using a Jenway 4510 Conductivity Meter.

\section{Validation of Relationships between $\mathrm{EC}_{\mathrm{e}}$ and $\mathrm{EC}$ of Soil-Water Extracts}

The $\mathrm{EC}_{\mathrm{e}}, \mathrm{EC}_{1: 2.5}$ and $\mathrm{EC}_{1: 5}$ values of the 21 soil samples were measured using the standard method and estimated using each one of the models. Regression equations were used to predict $\mathrm{EC}_{\mathrm{e}}$ equivalents from $\mathrm{EC}_{1: 2.5}$ and $\mathrm{EC}_{1: 5}$ measurements; the results were then compared with actual $\mathrm{EC}_{\mathrm{e}}$ measurements. To evaluate the best model to determine salinity of the tested coarse textured soils, we used the same samples to test models established by other researchers (Table 1). Values of $\mathrm{EC}_{\mathrm{e}}$ predicted by this study and other researchers' models were also compared with actual measurements via regression analysis (Table 4).

\section{Statistical Analysis}

Potential differences among methods were examined using a one-way analysis of variance set in a randomized complete block design. Post hoc mean separation was conducted using Fisher's protected least significant difference. Statistical computations were facilitated using GLM procedure and MEAN option of SAS 13.1 (SAS Institute, 2013). To assess the possible linear relationship of $\mathrm{EC}_{\mathrm{e}}$ to $\mathrm{EC}$ (1:2.5 or 1:5), simple linear regression models were run with either $\mathrm{EC}_{1: 2.5}$ or $\mathrm{EC}_{1: 5}$ as the dependent variable $(x)$ and the response of $\mathrm{EC}_{\mathrm{e}}$ as the independent $(y)$ variable. A validation study for these linear relationships using a paired t test was conducted to test the null hypothesis that the relationship between the measured values of $\mathrm{EC}_{\mathrm{e}}$ were the same as model-predicted values (i.e., the $Y$ intercept $=0$ and the slope $=1$ ). This validation study was conducted on an independent data set (21 samples total), and statistical computations were facilitated using the MEANS procedure of SAS 13.1 (SAS Institute, 2013).

The performance of the models was compared as well. Root mean square error (RMSE) was used as measure of model performance:

$$
R M S E=\sqrt{\frac{1}{N} \sum_{i=1}^{N}\left(E C_{1}-E C_{p}\right)^{2}}
$$

Where $\mathrm{N}$ is the number of observations, $\mathrm{EC}_{\mathrm{i}}$ is the measured value, and $\mathrm{EC}_{\mathrm{p}}$ is the predicted value based on the derived regression equations by this study and different studies (Table 4). The RMSE values were calculated for each model. The model with the least RMSE was assumed to predict $\mathrm{EC}_{\mathrm{e}}$ better than the other models.

\section{RERSULTS AND DISCUSSION}

\section{Electrical Conductivity of SP and Different Soil- Water Ratio Extracts}

The summary statistics for electrical conductivity of the soil samples are shown in Table 2. Electrical conductivity for the soil samples ranged from 0.29 to $18.35 \mathrm{dS} \mathrm{m}^{-1}$ for the SP extracts, from 0.08 to $4.53 \mathrm{dS}$ $\mathrm{m}^{-1}$ for the $1: 2.5$ extracts, and from 0.06 to $2.40 \mathrm{dS} \mathrm{m} \mathrm{m}^{-1}$ for 1:5 soil-water extracts, indicating that a wide range in salinity levels were obtained for comparing the SP with either $1: 2.5$ or $1: 5$ extraction methods.

Mean EC for saturated paste extracts was almost 4.5 fold greater than that of the 1:2.5 soil-water extracts, and approximately 8.3 fold greater than that of the 1:5 soilwater extracts. Our results are similar to those of other researchers who reported that the $\mathrm{EC}_{\mathrm{e}}$ extracts are greater than the EC of more diluted extracts (USDA, 1954; Hogg and Henry, 1984; Zhang et al., 2005; Ozcan et al., 2006; Sonmez et al., 2008; Aboukila and Norton, 2017).

These results are comparable to that from Sonmez et al. (2008) who reported that mean $\mathrm{EC}_{\mathrm{e}}$ was about four and eight fold greater than that of the $\mathrm{EC}_{1: 2.5}$ and $\mathrm{EC}_{1: 5}$, respectively. They concluded that about twofold diluted values are measured when soil-water ratios are increased about twofold. Zhang et al. (2005) and Sonmez et al. (2008) reported about twofold dilution when they compared the saturated paste result with 1:1 soil-water extract.

The considerable difference between the EC of soilwater extracts and $\mathrm{EC}_{\mathrm{e}}$ extracts is most likely due to a dilution effect that has been suggested by USDA (1954) and Rhoades (1982). Approximately $24 \%$ of the soils samples had an $\mathrm{EC}_{\mathrm{e}}<2 \mathrm{dS} \mathrm{m}^{-1}$ while approximately 85 $\%$ of the soils had an $\mathrm{EC}_{1: 2.5}<2 \mathrm{dS} \mathrm{m}^{-1}$ and $99 \%$ of the soils had an $\mathrm{EC}_{1: 5}<2 \mathrm{dS} \mathrm{m}^{-1}$ (Table 3 ).

\section{Relationship between $\mathrm{EC}_{\mathrm{e}}$ and $\mathrm{EC}_{1: 2.5}, \mathrm{EC}_{1: 5}$}

Electrical conductivity of SP versus that of different soil-water extracts is shown in Fig. 1. Different dilution ratios affected both the slope and the intercept of the regression line, although the slope was much more influential than the intercept (Table 1). A higher slope for the regression equations of $\mathrm{EC}$ was observed when soil-water ratio increased from 1:2.5 to 1:5, indicating that additional water causes dilution. Sonmez et al. (2008) considered the slopes of the regression equations as a dilution ratio. Electrical conductivity of SP was highly correlated with $\mathrm{EC}_{1: 2.5}$ and $\mathrm{EC}_{1: 5}$ for all soils $\left(\mathrm{R}^{2}=\right.$ 0.96-97, $P<0.001$ ) (Fig. 1).

The results of our study are similar to reportedthose reported by other researchers who found that highly 

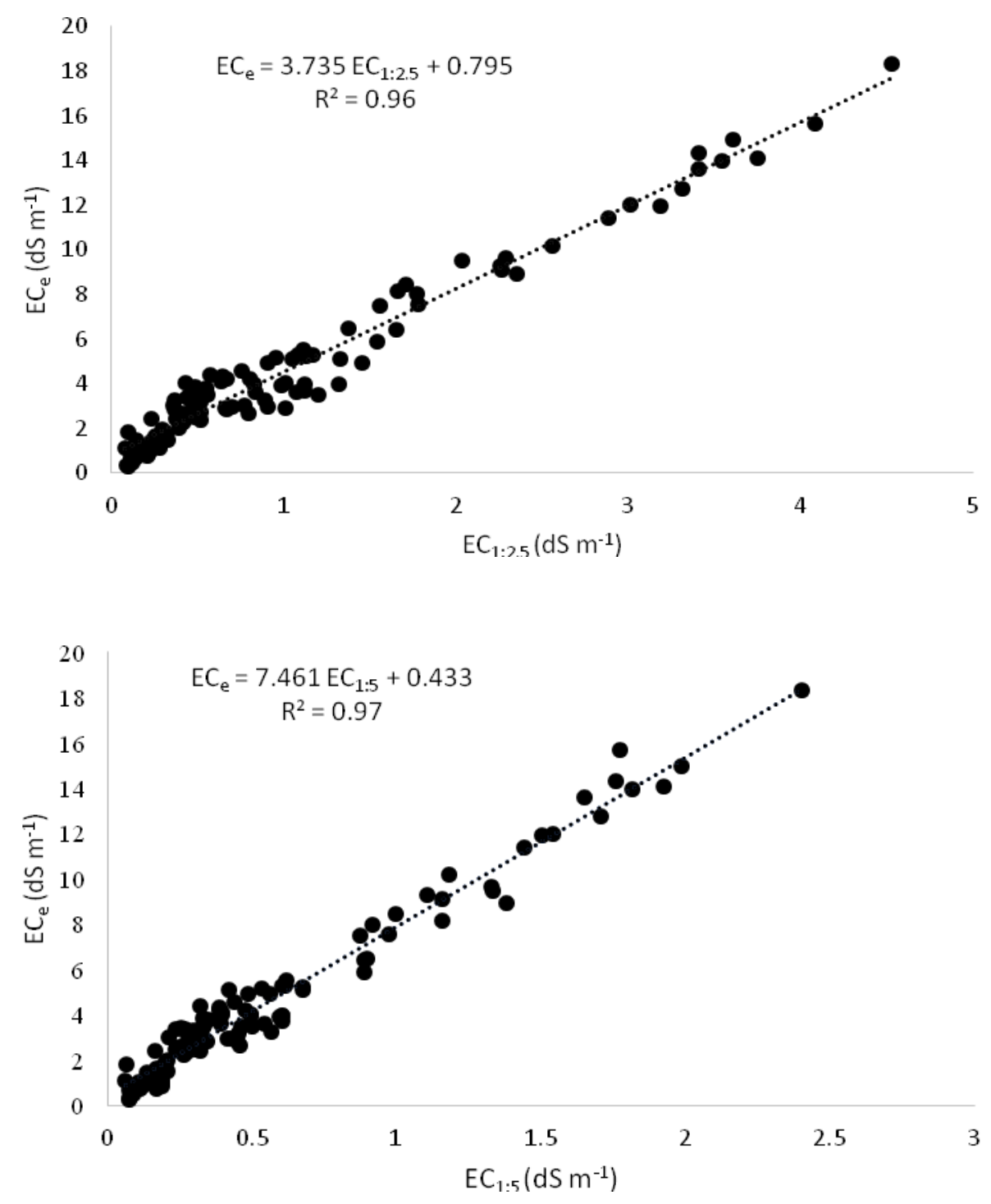

Fig. 1. Relationship between $E C$ of $S P$ extracts $\left(E C_{e}\right)$ and soil-water extracts $\left(E C_{1: 2.5}, E C_{1: 5}\right)$ for 115 study soil samples

Table 2. Summary statistics for selected physical and chemical properties of 115 soil samples used to establish relationships between saturated paste extracts $\left(\mathrm{ec}_{\mathrm{e}}\right)$ and two soil-water ratio extracts $\left(\mathrm{EC}_{1: 2.5}\right.$ and $\left.\mathrm{EC}_{1: 5}\right)$

\begin{tabular}{lccccccccc}
\hline & $\mathbf{E C}_{\mathbf{e}}$ & $\mathbf{E C}_{\mathbf{1}: \mathbf{2 . 5}}$ & $\mathbf{E C}_{\mathbf{1}: \mathbf{5}}$ & $\mathbf{p H}$ & $\mathbf{\%} \mathbf{C C E}$ & \% OM & Sand & Clay & Silt \\
\hline Mean & 4.52 & 1.01 & 0.55 & 7.36 & 1.17 & 0.40 & 73 & 9.6 & 17.4 \\
Median & 3.38 & 0.56 & 0.35 & 7.35 & 0.75 & 0.18 & 74 & 9.8 & 17.2 \\
Minimum & 0.29 & 0.08 & 0.06 & 6.85 & 0.01 & 0.02 & 56 & 4 & 5 \\
Maximum & 18.35 & 4.53 & 2.40 & 8.18 & 4.25 & 1.44 & 89 & 18 & 35 \\
St. Dev. & 3.82 & 1.01 & 0.50 & 0.28 & 0.99 & 0.44 & 11.7 & 4.8 & 10.7 \\
\hline
\end{tabular}

CCE, Calcium carbonate equivalent; St. Dev., Standard deviation. 
Table 3. Electrical conductivity of saturated paste extracts $\left(E C_{e}\right)$ and two soil-water ratio extracts $\left(E C_{1: 2.5}\right.$ and EC $1: 5)$ for the study soils

\begin{tabular}{|c|c|c|c|c|c|c|}
\hline \multirow{2}{*}{ 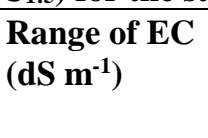 } & \multicolumn{2}{|l|}{$\mathrm{EC}_{\mathrm{e}}$} & \multicolumn{2}{|l|}{$\mathrm{EC}_{1: 2.5}$} & \multicolumn{2}{|l|}{$\mathrm{EC}_{1: 5}$} \\
\hline & $\begin{array}{l}\begin{array}{l}\text { No. of } \\
\text { samples }\end{array} \\
\end{array}$ & $\begin{array}{l}\% \text { of } \\
\text { samples }\end{array}$ & $\begin{array}{l}\begin{array}{l}\text { No. of } \\
\text { samples }\end{array} \\
\end{array}$ & $\begin{array}{l}\% \text { of } \\
\text { samples }\end{array}$ & $\begin{array}{l}\begin{array}{l}\text { No. of } \\
\text { samples }\end{array} \\
\end{array}$ & $\begin{array}{l}\% \text { of } \\
\text { samples }\end{array}$ \\
\hline $0-2$ & 28 & 24.3 & 98 & 85.2 & 114 & 99.1 \\
\hline $2-4$ & 45 & 39.1 & 15 & 13.0 & 1 & 0.9 \\
\hline$>4$ & 42 & 36.5 & 2 & 1.7 & 0 & 0 \\
\hline
\end{tabular}

significant relationships existed between the $\mathrm{EC}_{\mathrm{e}}$ and $\mathrm{EC}$ of either 1:2.5 extracts (Ozcan et al., 2006; Sonmez et al., 2008; Aboukila and Norton, 2017) or 1:5 extracts (Ozcan et al., 2006; Sonmez et al., 2008; Chi and Wang, 2010; Khorsandi and Yazdi, 2011; He et al., 2013; Klaustermeier et al., 2016; Monteleone et al., 2016; Aboukila and Norton, 2017).

Neither the slopes nor the $\mathrm{R}^{2}$ are changed much when intercepts are not included in the regression equations (Table 1). Forcing the regression line through zero slightly increased the slope from 3.73 to 4.13 and from 7.46 to 7.89 for the $1: 2.5$ and $1: 5$ relationships, respectively (Table 1).

The slopes obtained in this study are 3.73 and 7.46 for 1:2.5 and 1:5 extracts, respectively. The slope of 3.73 is close to the slope of 3.30 reported by Ozcan et al. (2006) and to the slope of 4.34 reported by Sonmez et al. (2008) for the same $\mathrm{EC}_{\mathrm{e}}$ and $\mathrm{EC}_{1: 2.5}$ relationships. The slope of 7.46 derived from the $\mathrm{EC}_{\mathrm{e}}$ and $\mathrm{EC}_{1: 5}$ relationship is similar to that of 8.22 reported by Sonmez et al. (2008). However, our results differed drastically from those of Ozcan et al. (2006), Khorsandi and Yazdi (2011), and Monteleone et al. (2016) who slope values of 5.97, 5.43 and 9.63, respectively, for the same $\mathrm{EC}_{\mathrm{e}}$ and $\mathrm{EC}_{1: 5}$ relationships.

The differences in regression equations reported by various researchers may be due to the clay content of the soil samples, as well as the type of clay (Sonmez et al., 2008), type of salts present (Richard and Gouny, 1965; Le Brusq and Loyer, 1982), gypsum content (Khorsandi and Yazdi, 2007, 2011) equilibration times and equilibration methods ( $\mathrm{He}$ et al., 2013) and the $\mathrm{EC}_{\mathrm{e}}$ range of soil samples used to develop the conversion equations (Aboukila and Norton, 2017).

\section{Validation of Models}

Twenty-one soil samples independent of those used to generate the regressions for this study were used to validate the relationships between $\mathrm{EC}_{\mathrm{e}}$ and the two $\mathrm{EC}_{1: 2.5}$ and $\mathrm{EC}_{1: 5}$. We used the same samples to test the models established by other researchers (Table 4 ).

The $\mathrm{EC}_{\mathrm{e}}$ means predicted by the regression equations of this study were 4.83 and $4.75 \mathrm{dS} \mathrm{m}^{-1}$ for $1: 2.5$ and $1: 5$ models, respectively. The predicted $\mathrm{EC}_{\mathrm{e}}$ were not significantly different $(P>0.05)$ than the mean actual measured $\mathrm{EC}_{\mathrm{e}}$ of $4.84 \mathrm{dS} \mathrm{m}^{-1}$ in the validation soils (Table 4). The discrepancies between the average measured and predicted values are $-0.27 \%$, and $-1.99 \%$ for $1: 2.5$ and 1:5 models, respectively.

The regression equations of Ozcan et al. (2006) resulted in $\mathrm{EC}_{\mathrm{e}}$ means of 3.37 and $2.28 \mathrm{dS} \mathrm{m}^{-1}$ for $1: 2.5$ and 1:5 models, respectively, which were significantly different $(P<0.01)$ than the mean actual measured $\mathrm{EC}_{\mathrm{e}}$ (Table 4). The difference between the average measured and estimated values are $-30.5 \%$, and $-52.9 \%$ for $1: 2.5$ and 1:5 models, respectively.

The $\mathrm{EC}_{\mathrm{e}}$ means determined using the regression equations of Sonmez et al. (2008) were 4.86 and 4.42 $\mathrm{dS} \mathrm{m}{ }^{-1}$ for 1:2.5 and 1:5 models, respectively. For 1:2.5 model, the predicted $\mathrm{EC}_{\mathrm{e}}$ mean was not significantly different $(P>0.05)$ than the mean of the actual measured $\mathrm{EC}_{\mathrm{e}}$, while, the predicted $\mathrm{EC}_{\mathrm{e}}$ mean from 1:5 model was significantly different $(P<0.05)$ than the mean of the actual measured $\mathrm{EC}_{\mathrm{e}}$ (Table 4). The difference between the average measured and predicted values are $0.34 \%$, and $-8.69 \%$ for $1: 2.5$ and $1: 5$ models, respectively.

The computed $\mathrm{EC}_{\mathrm{e}}$ for 1:5 soil to water ratios using the regression equations of Chi and Wang (2010), Khorsandi and Yazdi (2011), Monteleone et al. (2016), and Klaustermeier et al. (2016) were 0.98, 3.57, 5.57, and $3.31 \mathrm{dS} \mathrm{m}^{-1}$, respectively. The calculated $\mathrm{EC}_{\mathrm{e}}$ means were significantly different than mean of the actual measured $\mathrm{EC}_{\mathrm{e}}$ (Table 4). The discrepancies between the average measured and calculated values are -79.7, -26.3, 14.9, and $-31.7 \%$ for Chi and Wang (2010), Khorsandi and Yazdi (2011), Monteleone et al. (2016), and Klaustermeier et al. (2016), respectively.

Ideally, if the predicted values of $\mathrm{EC}_{\mathrm{e}}$ were exactly the same as the measured EC values, the slope would equal 1.0, $\mathrm{R}^{2}$ would equal 1.0, and the $y$ intercept would equal zero (Zhang et al., 2005). The regression line between measured and predicted values was not statistically different from the 1:1 bisecting line of the quadrant. The slope for the relationship between predicted and measured $\mathrm{EC}_{\mathrm{e}}$ was almost 1.0 for our models (Fig. 2), indicating that both models were more accurate than other models to determine salinity of the 
coarse textured soil, with $\mathrm{EC}_{\mathrm{e}}$ range between 0.29-18.35 $\mathrm{dS} \mathrm{m}^{-1}$.

Validation RMSE values were 0.61 and $0.70 \mathrm{dS} \mathrm{m}^{-1}$ for $\mathrm{EC}_{1: 2.5}$ and $\mathrm{EC}_{1: 5}$ values, respectively. Estimates for converting to saturated paste $\left(\mathrm{EC}_{\mathrm{e}}\right)$ values using a 1:2.5 soil-to-water ratio had the lowest RMSE values (Table 4). This indicates that $\mathrm{EC}_{1: 2.5}$ estimates were closer to the measured data than the $\mathrm{EC}_{1: 5}$ estimates.

Our newly developed equations were compared with 8 equations derived from six other EC conversion studies (Fig. 3; Table 4). The same validation data set, as mentioned previously, was used for the comparisons. Among the models developed here and the other 8 models reported in the literature, our 1:2.5 and 1:5 models were the most accurate followed by the models developed by Sonmez et al. (2008) at predicting $\mathrm{EC}_{\mathrm{e}}$ on studied soils based on RMSE, slop, $\mathrm{R}^{2}$, and predicted $\mathrm{EC}_{\mathrm{e}}$ values. This was expected since Sonmez et al. (2008) used soils with similar $\mathrm{EC}_{\mathrm{e}}$ range and soil texture as the present study to develop their model.

Models developed by Chi and Wang (2010), Ozcan et al. (2006) (1:5 model), and Khorsandi and Yazdi (2011) were the least accurate at predicting $\mathrm{EC}_{\mathrm{e}}$ from
$\mathrm{EC}_{1: 2.5}$ and $\mathrm{EC}_{1: 5}$ values, with RMSE of 4.56, 2.79, and $1.87 \mathrm{dS} \mathrm{m}{ }^{-1}$, respectively. In contrast, Sonmez et al. (2008) and our new models were the most accurate, with RMSE of $0.90-0.98$ and 0.61 to $0.70 \mathrm{dS} \mathrm{m} \mathrm{m}^{-1}$, respectively (Table 4). With the exception of the Sonmez et al. (2008) models, all other models produced RMSE of 2.4-7 times greater than those observed for the models presented in this study.

These differences in RMSE among models are likely due to the differences in soil texture, type of clay, salts present in the soil, presence of gypsum, equilibration times and equilibration methods and $\mathrm{EC}_{\mathrm{e}}$ range of soil samples used to establish the models.

Soil textural differences affect soil EC values in soilto-water extracts (Hogg and Henry, 1984; Sonmez et al., 2008). The equations developed by Aboukila and Norton (2017) (Table 1) for fine textured soil of El Beheira governorate, Egypt produced RMSE of 2.403.14 times greater than those observed for the equations presented in this study (data not shown). Therefore, improvements in conversion equation accuracy might be gained by differentiating soils by texture.

Table 4. Comparison of 8 developed $\mathrm{EC}$ conversion equations with $\mathrm{EC}_{1: 2.5}$ and $\mathrm{EC}_{1: 5}$ equations developed in this study

\begin{tabular}{|c|c|c|c|c|c|c|c|}
\hline Reference & Equation & $\begin{array}{c}\text { Measured } \\
\text { EC }_{e}\end{array}$ & $\begin{array}{l}\text { Predicted } \\
\text { EC }_{\mathrm{e}}\end{array}$ & $\begin{array}{c}\% \\
\text { difference }\end{array}$ & Slope & $\mathbf{R}^{2}$ & $\begin{array}{c}\text { RMS } \\
\text { E (dS } \\
\left.\mathbf{m}^{-1}\right)\end{array}$ \\
\hline $\begin{array}{l}\text { Ozcan et al. } \\
2006(1: 2.5)\end{array}$ & $\mathrm{EC}_{\mathrm{e}}=3.30 \mathrm{EC}_{1: 2.5}-0.20$ & 4.84 & $3.37^{* *}$ & -30.51 & 0.78 & 0.95 & 1.65 \\
\hline $\begin{array}{l}\text { Ozcan et al. } \\
2006(1: 5)\end{array}$ & $\mathrm{EC}_{\mathrm{e}}=5.97 \mathrm{EC}_{1: 5}-1.17$ & 4.84 & $2.28^{* *}$ & -52.90 & 0.60 & 0.89 & 2.79 \\
\hline $\begin{array}{l}\text { Sonmez et al. } \\
2008(1: 2.5)\end{array}$ & $\mathrm{EC}_{\mathrm{e}}=4.34 \mathrm{EC}_{1: 2.5}+0.17$ & 4.84 & $4.86^{\mathrm{NS}}$ & 0.34 & 1.07 & 0.97 & 0.98 \\
\hline $\begin{array}{l}\text { Sonmez et al. } \\
2008(1: 5)\end{array}$ & $\mathrm{EC}_{\mathrm{e}}=8.22 \mathrm{EC}_{1: 5}-0.33$ & 4.84 & $4.42^{*}$ & -8.69 & 0.97 & 0.96 & 0.90 \\
\hline $\begin{array}{l}\text { Chi and Wang } \\
2010(1: 5)\end{array}$ & $\mathrm{EC}_{\mathrm{e}}=11.68 \mathrm{EC}_{1: 5}-5.77$ & 4.84 & $0.98^{* *}$ & -79.73 & 0.77 & 0.56 & 4.56 \\
\hline $\begin{array}{l}\text { Khorsandi and } \\
\text { Yazdi 2011(1:5) }\end{array}$ & $\mathrm{EC}_{\mathrm{e}}=5.43 \mathrm{EC}_{1: 5}+0.43$ & 4.84 & $3.57^{* *}$ & -26.30 & 0.72 & 0.97 & 1.87 \\
\hline $\begin{array}{l}\text { Monteleone et } \\
\text { al. } 2016(1: 5)\end{array}$ & $\mathrm{EC}_{\mathrm{e}}=9.63 \mathrm{EC}_{1: 2.5}$ & 4.84 & $5.57^{*}$ & 14.95 & 1.19 & 0.97 & 1.54 \\
\hline $\begin{array}{l}\text { Klaustermeier et } \\
\text { al. } 2016(1: 5)\end{array}$ & $\mathrm{EC}_{\mathrm{e}}=10^{\left[1.256\left(\log \mathrm{EC}_{1: 5}\right)+0.766\right]}$ & 4.84 & $3.31^{* *}$ & -31.74 & 0.79 & 0.93 & 1.73 \\
\hline $\begin{array}{l}\text { This study }(1: 2.5 \\
\text { Model) }\end{array}$ & $\mathrm{EC}_{\mathrm{e}}=3.73 \mathrm{EC}_{1: 2.5}+0.79$ & 4.84 & $4.83^{\mathrm{NS}}$ & -0.27 & 1.00 & 0.98 & 0.61 \\
\hline $\begin{array}{l}\text { This study }(1: 5 \\
\text { Model) }\end{array}$ & $\mathrm{EC}_{\mathrm{e}}=7.46 \mathrm{EC}_{1: 5}+0.43$ & 4.84 & $4.75^{\mathrm{NS}}$ & -1.99 & 0.97 & 0.97 & 0.70 \\
\hline
\end{tabular}

NS Not significantly different from $\mathrm{EC}_{\mathrm{e}}$ measurement at $\alpha=0.1$.

"Significantly different from $\mathrm{EC}_{\mathrm{e}}$ measurement at $\alpha=0.05$.

${ }^{* * *}$ Significantly different from $\mathrm{EC}_{\mathrm{e}}$ measurement at $\alpha=0.01$.

RMSE, root mean square error. 


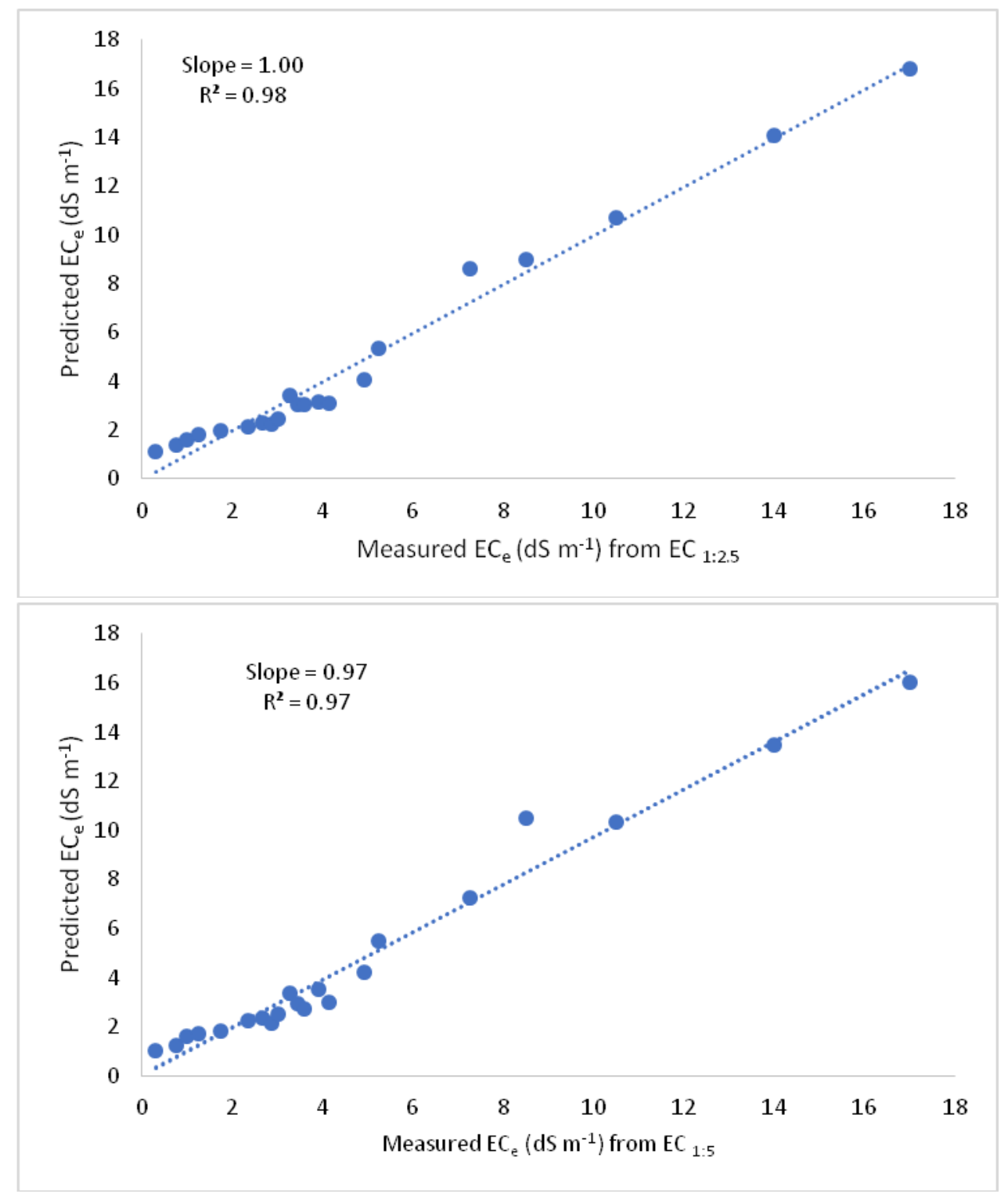

Fig. 2. Relationship between measured $\mathbf{E C}$ of $\mathrm{SP}$ extract $\left(\mathbf{E C}_{\mathrm{e}}\right)$ and predicted $\mathbf{E C}_{\mathrm{e}}$ from the regression equations obtained from 1:2.5 and 1:5 soil-water extracts for 21 samples used to validate the models shown in Fig1.

The new models presented here reduced errors by 2.4 to 7 times as compared with other equations reported in the literature. Therefore, our models are considering significant improvement for predicting $\mathrm{EC}_{\mathrm{e}}$ of coarse textured soils in El Beheira governorate than previous models reported in the literature. These models will be applicable to course textured soils. As these equations are valid for soil $\mathrm{EC}_{\mathrm{e}}$ from 0.3 to $18.3 \mathrm{dS} \mathrm{m}^{-1}$, they can be used for soils classified as both nonsaline and saline. We highly recommend that both 1:2.5 and 1:5 models be used in soil laboratories to determine soil salinity of coarse textured soil with $\mathrm{EC}_{\mathrm{e}}$ less than $18.35 \mathrm{dS} \mathrm{m}^{-1}$. 1:5 soil-water extract is easier to filter. However, 1:2.5

model would be the first choice to measure $\mathrm{EC}$ and $\mathrm{pH}$ in the same extract. The soil-water suspension of (1:2.5) prepared for $\mathrm{pH}$ measurements can be extracted and used for further EC measurements, minimizing time and cost associated with soil salinity studies.

The maximum $\mathrm{EC}_{\mathrm{e}}$ of soils used to develop the models was $18.35 \mathrm{dS} \mathrm{m}^{-1}$. However, we tested both models using four other samples with very high mean $\mathrm{EC}_{\mathrm{e}}$ of $43.2 \mathrm{dS} \mathrm{m}^{-1}$. The means predicted $\mathrm{EC}_{\mathrm{e}}$ were 40.9 and $41.6 \mathrm{dS} \mathrm{m}^{-1}$ for 1:2.5 and 1:5 models, respectively. The difference between the average measured and predicted values were $-5.3 \%$, and $-3.5 \%$ for $1: 2.5$ and 1:5 models, respectively. We determined that both 


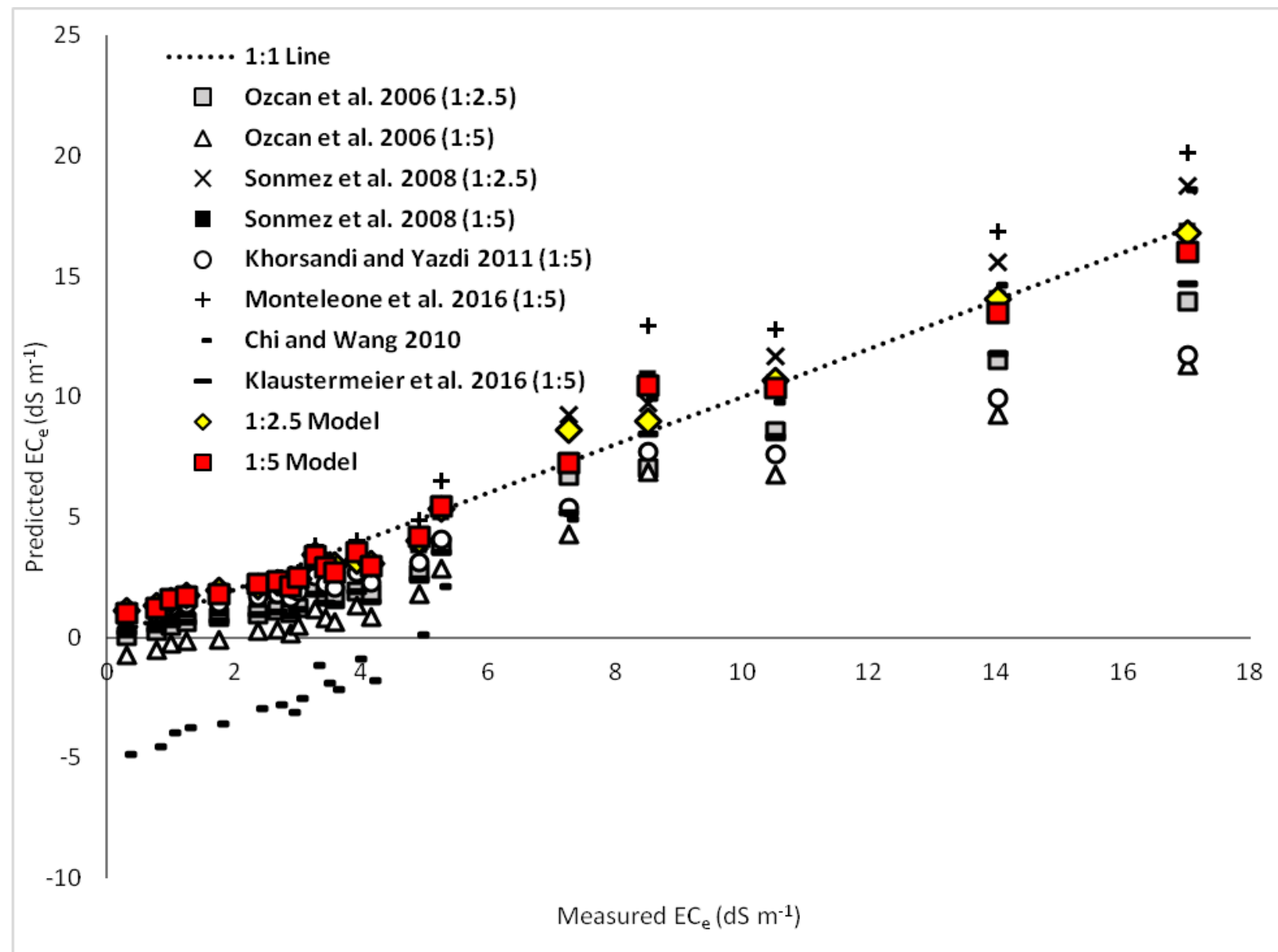

Fig 3. Comparison of 8 developed $\mathrm{EC}_{\mathrm{e}}$ conversion equations from six previous soil salinity studies with those developed in this study. Measured values are from a set of 21 validation soil samples

models could be used to test soil salinity for soil samples outside the studied $\mathrm{EC}_{\mathrm{e}}$ range. However, more studies are needed before it is recommended that both models be used for soil samples with $\mathrm{EC}_{\mathrm{e}}$ greater than $18.35 \mathrm{dS}$ $\mathrm{m}^{-1}$.

\section{CONCLUSION}

The relationships between $\mathrm{EC}_{\mathrm{e}}$ and both $\mathrm{EC}_{1: 2.5}$ and $\mathrm{EC}_{1: 5}$ were highly correlated $\left(\mathrm{R}^{2}=0.96-0.97, P<\right.$ 0.001 ), indicating strong evidence that $\mathrm{EC}_{\mathrm{e}}$ of coarse textured soils can be accurately estimated from $\mathrm{EC}_{1: 2.5}$ and $\mathrm{EC}_{1: 5}$ values using the newly developed models in this study. Based on model validations, using $\mathrm{EC}_{1: 2.5}$ to convert to $\mathrm{EC}_{\mathrm{e}}$ had the smallest RMSE values. Therefore, if possible, the $\mathrm{EC}_{1: 2.5}$ method should be used when evaluating soil salinity levels. However, both $\mathrm{EC}_{1: 2.5}$ and $\mathrm{EC}_{1: 5}$ models reduced errors by 2.4 - 7 times as compared with other conversion equations listed in the literature. The benefits of converting results of $\mathrm{EC}_{1: 2.5}$ or $\mathrm{EC}_{1: 5}$ to $\mathrm{EC}_{\mathrm{e}}$ are many. Soil laboratories may reduce the cost and time associated with soil salinity analysis by using these models, while still maintaining a high degree of precision and accuracy. Another benefit of measuring $\mathrm{EC}_{1: 2.5}$ is that $\mathrm{pH}$ measurements can be conducted on the same extract, minimizing time and cost associated with soil salinity analysis. These newly derived models will allow remediation specialist, and research scientists to assess the salinity of coarse textured soils more accurately than previous models reported in the literature. In summary, soil salinity of coarse textured soil can be accurately assessed for $\mathrm{EC}_{\mathrm{e}}$ values between 0.3 and $18.3 \mathrm{dS} \mathrm{m}^{-1}$ using the models generated by this study.

\section{ACKNOWLEDGMENTS}

We thank the College of Agricultural, Damanhour University, Egypt for funding this research.

\section{REFERENCES}

Aboukila E. F. and J. B. Norton. 2017. Estimation of saturated soil paste salinity from soil-water extracts. Soil Sci. 182 (3): 107-113. 
Alavi Panah, S. K. and M. De Dapper. 2001. Characterization of some soil salinity parameters in the playa margin (case study: Yazd Province). Iran Agric Res. 20:189-200.

Al-Busaidi, A., T. Yamamoto, C. Bakheit and P. Cookson. 2006. Soil salinity assessment by some destructive and non destructive methods in calcareous soils. J. Jpn. Soc. Soil Phys. 104:27-40.

Chi, C. M. and Z. C. Wang, 2010. Characterizing salt-affected soils of songnen plain using saturated paste and 1:5 soilto-water extraction methods. Arid Land Res. Mgmt. 24:111. doi:10.1080/15324980903439362.

Climate-Data.org. 2016. Climate: Beheira governorate (WWW Document). Available at: http://en.climatedata.org/region/1599/. Accessed March 15, 2016.

Corwin, D. L., S. M. Lesch and D. B. Lobell. 2012. Laboratory and field measurements, in Wallender, W. W., and Tanji, K. K. (Eds.), Agricultural Salinity Assessment and Management. second ed. Am. Soc. Civil Eng., New York, NY. pp. 295-341.

Day, S. J., J. B. Norton, T. J. Kelleners and C. F. Strom. 2015. Drastic disturbance of salt-affected soils in a semi-arid cool desert shrubland. Arid Land Res Manag. 29:306-320.

Fowler, D. B. and J. W. Hamm. 1980. Crop response to saline soil conditions in the parkland area of Saskatchewan. Can. J. Soil Sci. 60:439-449.

Franzen, D. 2003. Managing saline soils in North Dakota (WWW Document). North Dakota State University extension service, Fargo. Available at: https://www.ag.ndsu.edu/pubs/plantsci/soilfert/sf1087.pdf. Accessed April 2, 2016.

Gee, G. W. and J. W. Bauder. 1986. Particle size analysis, in Klute, A. (Ed.), Methods of Soil Analysis, part 1: Physical and mineralogical methods, $2^{\text {nd }}$ ed. SSSA. Madison, WI, USA, pp. 383-411.

He. Y., T. De Sutter, L. Prunty, D. Hopkins, X. Jia, and D. Wysocki. 2013. Predicting ECe of the saturated paste extract from value of EC1:5 Can. J. Soil Sci. 93:585-594.

Herrero, J., and O. Pérez-Coveta. 2005. Soil salinity changes over 24 years in a Mediterranean irrigated district. Geoderma. 125:287-308.

Hogg, T. J. and J. L. Henry. 1984. Comparison of 1:1 and 1:2 suspensions and extracts with the saturation extract in estimating salinity in Saskatchewan soils. Can. J. Soil Sci. 64:669-704.

Khorsandi, F. and F. A. Yazdi. 2007. Gypsum and texture effects on the estimation of saturated paste electrical conductivity by two extraction methods. Commun. Soil Sci. Plant Anal. 38:1105-1117.

Khorsandi, F. and F. A. Yazdi. 2011. Estimation of saturated paste extracts' electrical conductivity from 1:5 soil/water suspension and gypsum. Commun. Soil Sci. Plant Anal. 42:315-321.

Klaustermeier, A., H. Tomlinson, A. L. M. Daigh, R. Limb, T. DeSutter and K. Sedivec. 2016. Comparison of soil-towater suspension ratios for determining electrical conductivity of oil-production-water-contaminated soils. Can. J. Soil Sci. 96: 233-243.

Kruse, E. G., L. Willardson and J. Ayars. 1990. On-farm irrigation and drainage practices, in Tanji K. K. (Ed.), Agricultural Salinity Assessment and Management. Am. Soc. Civil Eng., New York, NY. pp. 349-371.

Le Brusq, J. Y. and J. V. Loyer. 1982. Relations entre les mesures de conductivités sur des extracts de sols de rapports sol/solution variables dans la vallée del fleuve Senégal. Cahiers ORSTOM, série Pédologie. 19:293-301.

McKenzie, R. C., C. H. Sprout and N. F. Clark. 1983. The relationships of the yield of irrigated barley to soil salinity as measured by several methods. Can. J. Soil Sci. 63:519528.

Monteleone, M., G. Lacolla, G. Caranfa and G. Cucci. 2016. Indirect measurement of electrical conductivity and exchangeable cations on soil water extracts: assessing the precision of the estimates. Soil Sci. 181:465-471.

Nelson, D. W. and L. E. Sommers. 1982. Total carbon, organic carbon and organic matter, in Page A. L. (Ed.), Methods of Soil Analysis, part 2: Chemical and microbiological properties, second ed. ASA. Madison, WI, USA, pp. 539-549.

Nelson, R. E. 1982. Carbonate and gypsum, in Page A. L. (Ed.), Methods of Soil Analysis, part 2: Chemical and microbiological properties, second ed. ASA. Madison, WI, USA, pp. 181-197.

Ozcan, H., H. Ekinci, Y. Yigini and O. Yuksel. 2006. Comparison of four soil salinity extraction methods. Proceedings of 18th International Soil Meeting on "Soil Sustaining Life on Earth, Managing Soil and Technology", May 22-26, 2006, Sanliurfa, Turkey. pp. 697-703.

Pitman, M. G. and A. Lauchli. 2002. Global impacts of salinity and agricultural ecosystems, in: Lauchli A., and U. Lüttge, (Eds.), Salinity: Environment-Plants-Molecules. Kluwer Academics, pp. 3-20.

Rhoades, J. D. 1982. Soluble salts, in Page, A. L. (Ed.), Methods of Soil Analysis, part 2: Chemical and microbiological properties, $2^{\text {nd }}$ ed. ASA. Madison, WI, USA, pp. 167-179.

Rhoades, J. D. 1996. Salinity: Electrical conductivity and total dissolved salts, in Sparks D. L., A. L. Page, P. A. Helmke, R. H. Loeppert, P. N. Soltanpour, M. A. Tabatabai, C. T. Johnston, and M. E. Sumner (Eds.), Methods of Soil Analysis. Part 3: Chemical methods, SSSA Book series No. 5. ASA and SSSA, Madison, WI, USA, pp. 417-436.

Rhoades, J. D., F.Chanduvi, S.Lesch. 1999. Soil salinity assessment. Methods and Interpretation of Electrical Conductivity Measurements. FAO Irrigation and Drainage Paper 57 Food and Agriculture Organization of the United Nations, Rome.

Richard, M. and P. Gouny. 1965. Soil salinity test. Annales agronomiques. 16:625-635.

SAS Institute. 2013. SAS 13.1 software. SAS Inst., Cary, NC: SAS Institute Inc. 
Shirokova, Y., I. Forkutsa and N. Sharafutdinova. 2000. Use of electrical conductivity instead of soluble salts for soil salinity monitoring in Central Asia. Irrig. Drain. Syst. 14:199-205.

Soil Survey Staff. 2011. Soil survey laboratory information manual. Soil Survey Investigations Report No. 45, Version 2.0. Burt, R., (Ed.). Aqueous extraction, Method 4.3.3. USDA-NRCS, Lincoln, NE, pp. 167.

Soil Survey Staff. 2014. Keys to soil taxonomy. 12th ed. USDA-Natural Resources Conservation Service, Washington, DC.

Sonmez, S., D. Buyuktas, F. Okturen and S. Citak. 2008. Assessment of different soil to water ratios $(1: 1,1: 2.5$, 1:5) in soil salinity studies. Geoderma. 144:361-369.
USDA. 1954. Diagnoses and improvement of saline and alkali soils. Agric. Handbook No. 60. USSL, Riverside, CA, USA.

Wagenet, R. J. and J. J. Jurinak. 1978. Spatial variability of soluble salt content in a mancos shale watershed. Soil Sci. 126:342-349.

Wang, Y., Z. X. Wang, X. J. Lian, H. Xiao, L. Y. Wang and H. D. He. 2011. Measurement of soil electrical conductivity and relationship between soluble salt content and electrical conductivity in Tianjin coastal area. Tianjin Agric. Sci. 17:18-21.

Zhang, H., J. L. Schroder, J. J. Pittman, J. J. Wang and M. E. Payton. 2005. Soil salinity using saturated paste and 1:1 soil to water extract. Soil Sci. Soc. Am. J. 69:1146-1151.

\section{الملخص العربي}

\section{تقدير ملوحة عجينه التربة المشبعة باستخدام مستخلصات التربة المائية 1:2.5 و 1:5 للأراضي الخشنة القوام

$$
\text { عماد فاروق أبوكيلة وعماد فوزي عبد العاطى }
$$

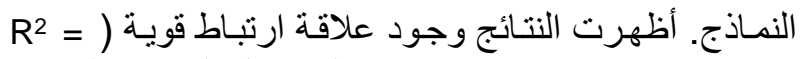

0.96 to 0.97, $P$ > 0.001 التربة المشبعة (ECe

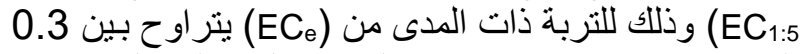

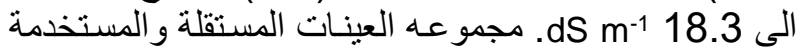

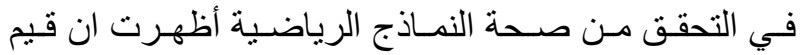

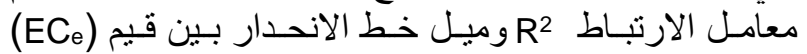

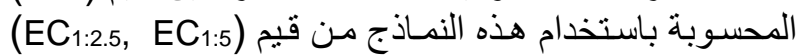

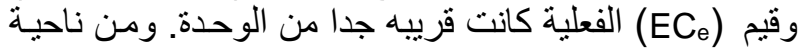

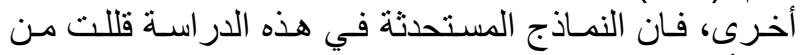

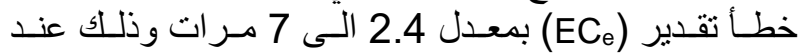

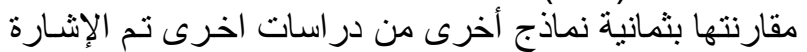

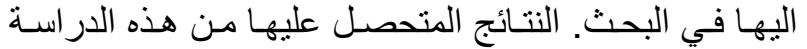

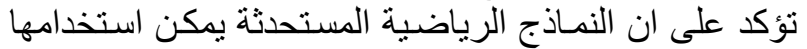

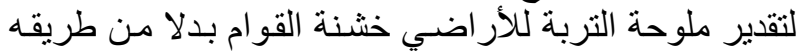

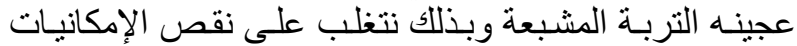
و أيضا نقلل من الوقت و الجنه و والتكاليف.
من الضروري تقدير ملوحة التربة باستخدام طريقة دقيقهـ

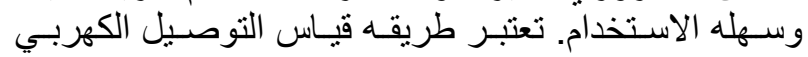

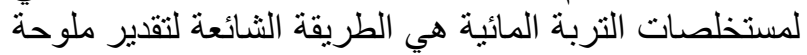

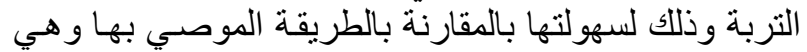

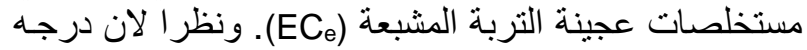

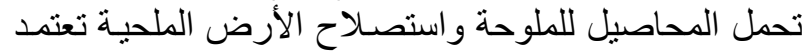

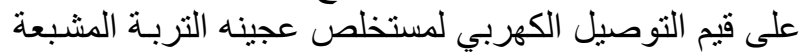

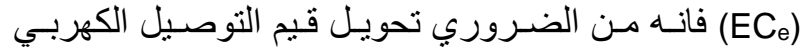

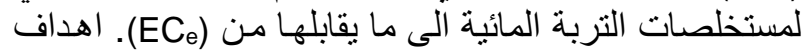
هذه الدر اسة هو استحداث نماذج رياضيه لاستنتاج قيم (EC)

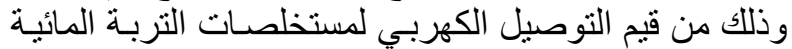

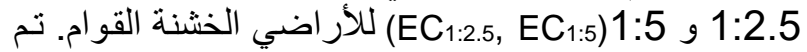

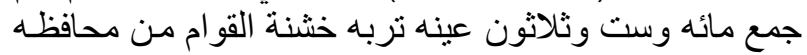

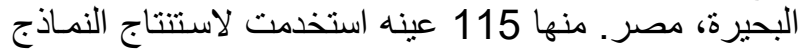

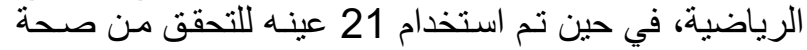

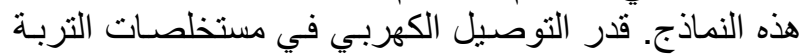

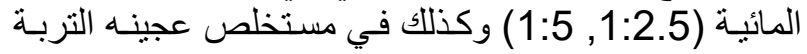
المشبعة. تم استخدام معـادلات الانحدار الخطى للتنبؤ بهذه 